\title{
Plasma hormone levels and reproductive behaviour in anoestrous ewes after treatment with progesterone and PMSG
}

\author{
N. F. Cunningham, N. Saba, C. D. H. Boarer and J. J. P. Hattersley \\ Central Veterinary Laboratory, Ministry of Agriculture, Fisheries \& Food, New Haw, \\ Weybridge, Surrey, KT15 3NB, U.K.
}

\begin{abstract}
Summary. Plasma progesterone and gonadotrophin levels were studied in anoestrous ewes treated during June or July with a subcutaneous progesterone implant and/or an injection of oestradiol or PMSG. Of 32 ewes treated with progesterone during July, 9 showed a gonadotrophin surge after removal of the implant, and 10 ewes showed oestrous behaviour during the following 4 days. Six ewes conceived at this induced oestrus. Progesterone treatment during June was much less effective, with only 2 of 19 treated ewes showing a gonadotrophin surge and oestrous behaviour. Administration of PMSG at the time of implant removal in the June experiment was followed by a gonadotrophin surge and oestrous behaviour in 18 of 19 ewes, and 15 ewes conceived at the induced oestrus. An injection of PMSG, without progesterone pretreatment, stimulated a gonadotrophin surge and ovulation, but did not result in oestrous behaviour. The treatments employed appeared to initiate cyclic ovarian activity in the July experiment, but not in the June experiment.
\end{abstract}

\section{Introduction}

Seasonally anoestrous ewes can be induced to show a fertile oestrus by a period of treatment with progesterone or a synthetic progestagen followed by an injection of PMSG (Gordon, 1971; Boland \& Gordon, 1973). Saba, Cunningham, Symons \& Millar (1975) reported that treatment of ewes with progesterone during July-August induced ovulation, but there was a low incidence of overt oestrus, and Boland \& Gordon (1973) concluded that, in the absence of PMSG, progestagen treatments resulted in only a limited ovulatory response with a high proportion of ewes having 'silent' heats. It has also been reported that fertility is improved by the administration of oestradiol to anoestrous ewes at the start of progesterone treatment (Hulet \& Stormshak, 1972). In the present paper we present data on plasma hormone levels, reproductive behaviour and fertility in anoestrous ewes treated during July and June of 2 consecutive years with subcutaneous progesterone implants and/or oestradiol or PMSG injections.

\section{Materials and Methods}

\section{Progesterone implants}

Solid Silastic implants $(10 \mathrm{~cm}$ long $\times 0.5 \mathrm{~cm}$ diam) containing 0,13 or $20 \%(\mathrm{w} / \mathrm{w})$ progesterone were prepared according to the method of Mauer et al. (1972) using Dow Corning 382 Medical Grade Elastomer as described previously (Cunningham, Saba \& Millar, 1975). The 13 and $20 \%$ progesterone implants contained $\sim 260$ and $\sim 460 \mathrm{mg}$ progesterone, respectively. 


\section{Experimental animals and treatments}

Experiment 1. Fifty (50) Cheviot $\times$ Border Leicester ewes aged 18 months, which would normally be expected to begin cycles in October, were housed in 4 indoor pens at the beginning of July. The ewes were divided into 3 groups treated as shown in Table 1. The implants were inserted subcutaneously on $11 \mathrm{July}$ using the technique described earlier (Symons, Cunningham, Saba \& Millar, 1974) and after 11 days were removed from half of the ewes at 09:00 h (subgroups A) and from the remainder at $21: 00 \mathrm{~h}$ (subgroups B). At the time of implant insertion, ewes in Groups 1 and 3 received an intramuscular injection of a fine suspension of 500 $\mu \mathrm{g}$ oestradiol- $17 \beta$ in $2 \mathrm{ml} 0.9 \%(\mathrm{w} / \mathrm{v}) \mathrm{NaCl}$. Group-2 ewes were injected with $2 \mathrm{ml} 0.9 \%(\mathrm{w} / \mathrm{v})$ $\mathrm{NaCl}$.

Table 1. Treatments of anoestrous ewes receiving a subcutaneous progesterone or blank Silastic implant for 11 (Exp. 1) or 14 (Exp. 2) days

\begin{tabular}{cclll}
\hline & No. of & & \multicolumn{2}{c}{ Treatment } \\
\cline { 4 - 5 } Group & ewes & Type of implant & At insertion & At removal \\
\hline $\begin{array}{c}\text { Experiment } 1 \\
1\end{array}$ & 6 & Blank & Oestradiol & - \\
2 & 14 & $20 \%$ progesterone & NaCl & - \\
3 & 30 & $20 \%$ progesterone & Oestradiol & - \\
Experiment 2 & & & & \\
4 & 6 & Blank & - & Solvent \\
5 & 10 & Blank & - & PMSG \\
6 & 20 & $13 \%$ progesterone & - & Solvent \\
7 & 20 & $13 \%$ progesterone & - & PMSG \\
\hline
\end{tabular}

Experiment 2. The following year, 49 of the Cheviot Cross ewes and an additional 7 North Country $\times$ Suffolk Cross halfbreed ewes of about the same age were housed at the beginning of May. Treatment (as shown in Table 1) commenced on 2 June, and the implants were removed 14 days later, half of the ewes having the implants removed at 17:30 h (subgroups A) and the remainder at $05: 30 \mathrm{~h}$ (subgroups B). Immediately following removal of the implant, each ewe in Groups 5 and 7 received an intramuscular injection of 500 i.u. PMSG in $1.3 \mathrm{ml} 0.5 \%$ phenol (Folligon: Intervet), and ewes in Groups 4 and 6 received $1.3 \mathrm{ml}$ solvent alone ( $0.5 \%$ phenol).

\section{Blood sampling}

Samples of jugular blood were collected in heparinized Vacutainers before insertion of the implants and at 1,5 and 11 days (Exp. 1) or 1, 7 and 14 days after implantation (Exp. 2). Following removal of the implants, samples were collected every $3 \mathrm{~h}$ for $72 \mathrm{~h}$ (Exp. 1) or every 4 $\mathrm{h}$ for $96 \mathrm{~h}$ (Exp. 2) and at 1-3 day intervals thereafter until 3 weeks after implant removal. Blood plasma was stored at $-20^{\circ} \mathrm{C}$ until required for hormone assays.

\section{Radioimmunoassay of hormones}

Plasma FSH and LH were determined by the polystyrene tube radioimmunoassays previously described (Cunningham \& Hebert, 1973; Symons, Cunningham \& Saba, 1974). Sensitivities of the assays were $0.4 \mathrm{ng} \mathrm{NIH-FSH}-\mathrm{S} 4 /$ tube and $2.5 \mathrm{ng} \mathrm{NIH-LH-S17/tube,} \mathrm{and}$ inter- and intra-assay coefficients of variation were respectively 15 and $5 \%$ for FSH and 12 and $8 \%$ for LH. Plasma progesterone was estimated in Exp. 1 by a modification (Symons, 1973) of the dextran-coated charcoal radioimmunoassay for oestrogens described by Challis, Heap \&

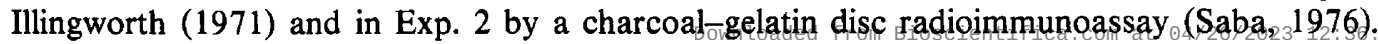


Antiserum S49-6 (obtained from Dr G. E. Abraham) was used for both experiments; this was raised in sheep against 11-desoxycortisol-21-hemisuccinate-HSA and its specificity has been described (Abraham, Swerdloff, Tulchinsky \& Odell, 1971). The assays were sensitive to $25 \mathrm{pg}$ progesterone/tube and inter- and intra-assay coefficients of variation were 16 and $6 \%$ respectively.

\section{Reproductive behaviour}

Four rams fitted with marking harnesses were run with the ewes for 5 weeks from 1 week after insertion of the implants. Each ram was penned with 12-14 ewes and rams were changed between pens periodically. Ewes were examined daily for signs of marking by the rams and those having a definite marking were removed from the rams to a separate pen.

In Exp. 2, mating by the rams was confirmed by taking samples of vaginal mucus from marked ewes and examining them under the microscope for the presence of spermatozoa.

\section{Results}

In Exp. 1, 7 ewes from Group 2 and 5 from Group 3 developed abscesses and fibrous tissue around the implants, presumably a reaction to the local high concentration of progesterone. Absorption of progesterone from the implants in these ewes, as evidenced by loss of weight of the implants and plasma progesterone levels during the period of implantation, was reduced compared to that in ewes which did not develop abscesses. Results from these 12 ewes have therefore not been included.

One ewe from Group 6A and 1 from Group 7B lost their implants before Day 14 after implant insertion and results from these 2 ewes have also been excluded from consideration.

\section{Effects of implants on plasma progesterone levels}

Mean ( \pm s.e.m.) plasma progesterone levels during the period of implantation for the 2 experiments are summarized in Table 2. Data for Groups 2 and 3 (Exp. 1) have been pooled, since there was no significant difference in mean plasma progesteronc concentration between these 2 groups at any of the times studied. In both experiments insertion of progesterone implants was followed by a significant rise in plasma progesterone concentration at $24 \mathrm{~h}(n<$ $0.001)$, and there was a significant fall in the level $12 \mathrm{~h}$ after implant removal $(P<0.001)$. By contrast, ewes treated with a blank implant showed little change in mean plasma progesterone level after insertion or removal of the implants.

Table 2. Mean ( \pm s.e.m.) plasma progesterone concentrations $(\mathrm{ng} / \mathrm{ml})$ in anoestrous ewes treated for 11 or 14 days with subcutaneous implants containing 0,13 or $20 \%(w / w)$ progesterone

\begin{tabular}{|c|c|c|c|c|c|c|c|c|c|}
\hline \multirow{2}{*}{\multicolumn{2}{|c|}{$\begin{array}{c}\text { Progesterone } \\
\text { content of } \\
\text { Exp. implant }(\mathrm{mg})\end{array}$}} & \multirow{2}{*}{$\begin{array}{l}\text { No. } \\
\text { of } \\
\text { ewes }\end{array}$} & \multicolumn{6}{|c|}{ Time after insertion of implant (days) } & \multirow{2}{*}{$\begin{array}{l}12 \mathrm{~h} \text { after } \\
\text { implant } \\
\text { removal }\end{array}$} \\
\hline & & & 0 & 1 & 5 & 7 & 11 & 14 & \\
\hline \multirow[t]{2}{*}{1} & 0 & 6 & $\begin{array}{r}0.61 \\
\pm 0.10\end{array}$ & $\begin{array}{r}0.71 \\
\pm 0.06\end{array}$ & $\begin{array}{r}0.33 \\
\pm 0.05\end{array}$ & - & $\begin{array}{r}0.52 \\
+0.17\end{array}$ & - & $\begin{array}{r}0.73 \\
\pm 0.21\end{array}$ \\
\hline & 460 & 32 & $\begin{array}{r}0.96 \\
+0.07\end{array}$ & $\begin{array}{c}3.84 \\
\pm 0.18^{*}\end{array}$ & $\begin{array}{r}1.92 \\
+0.11\end{array}$ & - & $\begin{array}{r}1.67 \\
+0.10\end{array}$ & - & $\begin{array}{r}0.56 \\
+0.06^{*}\end{array}$ \\
\hline \multirow[t]{2}{*}{2} & 0 & 16 & $\begin{array}{r}0.35 \\
\pm 0.04\end{array}$ & $\begin{array}{r}0.30 \\
\pm 0.05\end{array}$ & - & $\begin{array}{r}0.25 \\
\pm 0.03\end{array}$ & - & $\begin{array}{r}0.27 \\
\pm 0.04\end{array}$ & $\begin{array}{r}0.30 \\
\pm 0.04\end{array}$ \\
\hline & 260 & 38 & $\begin{array}{r}0.12 \\
\pm 0.02\end{array}$ & $\begin{array}{c}0.80 \\
\pm 0.06^{*}\end{array}$ & - & $\begin{array}{r}0.57 \\
+0.04\end{array}$ & - & $\begin{array}{r}0.49 \\
+0.03\end{array}$ & $\begin{array}{c}0.19 \\
+0.03^{*}\end{array}$ \\
\hline
\end{tabular}


At the end of the period of implantation, mean ( \pm s.e.m.) loss of weight of the implants was $86.4 \pm 1.6 \mathrm{mg}$ for those containing $20 \%$ progesterone $(n=32)$ and $87.2 \pm 2.0 \mathrm{mg}$ for those containing $13 \%$ progesterone $(n=38)$, whereas mean loss of weight of blank implants in the 2 experiments was $2.3 \pm 1.0 \mathrm{mg}$ (Exp. $1, n=6$ ) and $4.8 \pm 1.0 \mathrm{mg}($ Exp. $2, n=16)$. These data suggest that the implants released approximately $84 \mathrm{mg}$ progesterone over 11 days in Exp. 1 and $82 \mathrm{mg}$ progesterone over 14 days in Exp. 2.

\section{Experiment 1}

Changes in plasma hormone levels following implant removal

The time of day at which the implant was removed $09: 00 \mathrm{~h}$ and $21: 00 \mathrm{~h}$ for subgroups A and B) had no effect on the pattern of hormonal responses following implant removal, and the data for subgroups $\mathrm{A}$ and $\mathrm{B}$ have therefore been combined.

Gonadotrophins. At the time of implant removal, mean ( \pm s.e.m.) plasma LH level in 6 ewes treated with a blank implant $(5.6 \pm 0.6 \mathrm{ng} / \mathrm{ml})$ was not significantly different from that in ewes of Groups $2(6.4 \pm 0.7 \mathrm{ng} / \mathrm{ml}, \mathrm{N}=7)$ and $3(4.9 \pm 0.3 \mathrm{ng} / \mathrm{ml}, \mathrm{N}=25)$ treated with a progesterone implant. However, mean plasma FSH level was significantly higher $(P<0.01)$ in Group-3 ewes $(53.8 \pm 3.6 \mathrm{ng} / \mathrm{ml})$ treated with oestradiol and progesterone than in ewes of Groups $1(33 \cdot 8 \pm 4 \cdot 1 \mathrm{ng} / \mathrm{ml})$ and $2(31.4 \pm 5 \cdot 3 \mathrm{ng} / \mathrm{ml})$.

Data on plasma gonadotrophin surges following implant removal are summarized in Table 3 . Nine ewes treated with a $20 \%$ progesterone implant (Groups 2 and 3 ) showed a gonadotrophin

Table 3. Plasma gonadotrophin surges and reproductive behaviour of anoestrous ewes treated with a progesterone or blank implant for 11 or 14 days

\begin{tabular}{|c|c|c|c|c|c|c|c|}
\hline \multirow[b]{2}{*}{$\begin{array}{l}\text { Group: } \\
\text { Implant: }\end{array}$} & \multicolumn{3}{|c|}{ Experiment 1 ( 11 days) } & \multicolumn{4}{|c|}{ Experiment 2 ( 14 days) } \\
\hline & $\stackrel{1}{\text { Blank }}$ & $\begin{array}{c}2 \\
20 \% \\
\text { progesterone }\end{array}$ & $\begin{array}{c}3 \\
20 \% \\
\text { progesterone }\end{array}$ & $\begin{array}{c}4 \\
\text { Blank }\end{array}$ & $\begin{array}{c}5 \\
\text { Blank }\end{array}$ & $\begin{array}{c}6 \\
13 \% \\
\text { progesterone }\end{array}$ & $\begin{array}{c}7 \\
13 \% \\
\text { progesterone }\end{array}$ \\
\hline $\begin{array}{l}\text { Treatment } \\
\text { At insertion: } \\
\text { At removal: }\end{array}$ & Oestradiol & $\stackrel{\mathrm{NaCl}}{-}$ & $\begin{array}{c}\text { Oestradiol } \\
-\end{array}$ & Solvent & $\overline{\mathrm{PMSG}}$ & Solvent & $\overline{P M S G}$ \\
\hline No. of ewes & 6 & 7 & 25 & 6 & 10 & 19 & 19 \\
\hline $\begin{array}{l}\text { No. showing a } \\
\text { gonadotrophin } \\
\text { surge within } \\
72 \mathrm{~h}^{*}\end{array}$ & 0 & 4 & 5 & 0 & 10 & 0 & 18 \\
\hline $\begin{array}{l}\text { Time of surge } \\
\text { (h) } \dagger\end{array}$ & - & $48 \cdot 5 \pm 6 \cdot 7$ & $52.5 \pm 4.9$ & - & $27.4 \pm 0.9$ & - & $32 \cdot 7 \pm 0.5$ \\
\hline $\begin{array}{l}\text { Peak gonado- } \\
\text { trophin levels } \dagger\end{array}$ & & & & & & & \\
\hline $\begin{array}{l}\mathrm{LH}(\mathrm{ng} / \mathrm{ml}) \\
\mathrm{FSH}(\mathrm{ng} / \mathrm{ml})\end{array}$ & - & $\begin{array}{r}99.5 \pm 19.1 \\
238.5 \pm 31.7\end{array}$ & $\begin{array}{c}59.7 \pm 9.8 \\
233.8 \pm 19.0\end{array}$ & - & $\begin{array}{r}78 \cdot 4 \pm 12 \cdot 6 \\
158 \cdot 3 \pm 21 \cdot 4\end{array}$ & - & $\begin{array}{r}63.4 \pm 5.8 \\
147.9 \pm 9.4\end{array}$ \\
\hline $\begin{array}{l}\text { No. showing a } \\
\text { gonadotrophin } \\
\text { surge at } 75-96 \\
\mathrm{~h}^{*}\end{array}$ & 一 & 二‡ & 二 & 3 & 1 & 2 & 0 \\
\hline $\begin{array}{l}\text { No. of ewes } \\
\text { mated during } \\
\text { 1st } 4 \text { days* }\end{array}$ & 0 & 4 & 6 & 0 & 0 & 2 & 18 \\
\hline $\begin{array}{l}\text { No. of ewes } \\
\text { lambing }\end{array}$ & - & 3 & 3 & - & - & 1 & 15 \\
\hline No. of lambs & - & 4 & 3 & - & - & 1 & 29 \\
\hline
\end{tabular}

* All times are relative to implant removal at time 0.

$\dagger$ Mean \pm s.e.m.

$\ddagger$ Not sampled. 
surge during the $72 \mathrm{~h}$ following implant removal, with peak plasma LH concentrations ranging from 33 to $156 \mathrm{ng} / \mathrm{ml}$. All ewes showing an LH surge exhibited a simultaneous rise in plasma FSH concentration to peak values ranging from 170 to $330 \mathrm{ng} / \mathrm{ml}$. None of the ewes treated with a blank implant exhibited a gonadotrophin surge during this period (Table 3 ).

Progesterone. All 9 ewes in which a gonadotrophin surge was observed showed a pattern of rising plasma progesterone concentration to values $>1 \mathrm{ng} / \mathrm{ml}$ by 11 days after implant removal. In addition, 1 ewe in Group 3 which had not exhibited a gonadotrophin surge showed a similar plasma progesterone pattern and presumably had a gonadotrophin surge later than $72 \mathrm{~h}$. Mean plasma progesterone levels for these 10 ewes during the 18 days following implant removal are shown in Text-fig. 1.

Plasma progesterone levels were not elevated in the remaining 28 ewes, and on Day 11 after implant removal mean ( \pm s.e.m.) plasma progesterone concentrations were $0.19 \pm 0.03 \mathrm{ng} / \mathrm{ml}$ (blank implant, $\mathrm{N}=6$ ) and $0.19 \pm 0.04 \mathrm{ng} / \mathrm{ml}$ (progesterone implant, $\mathrm{N}=22$ ).

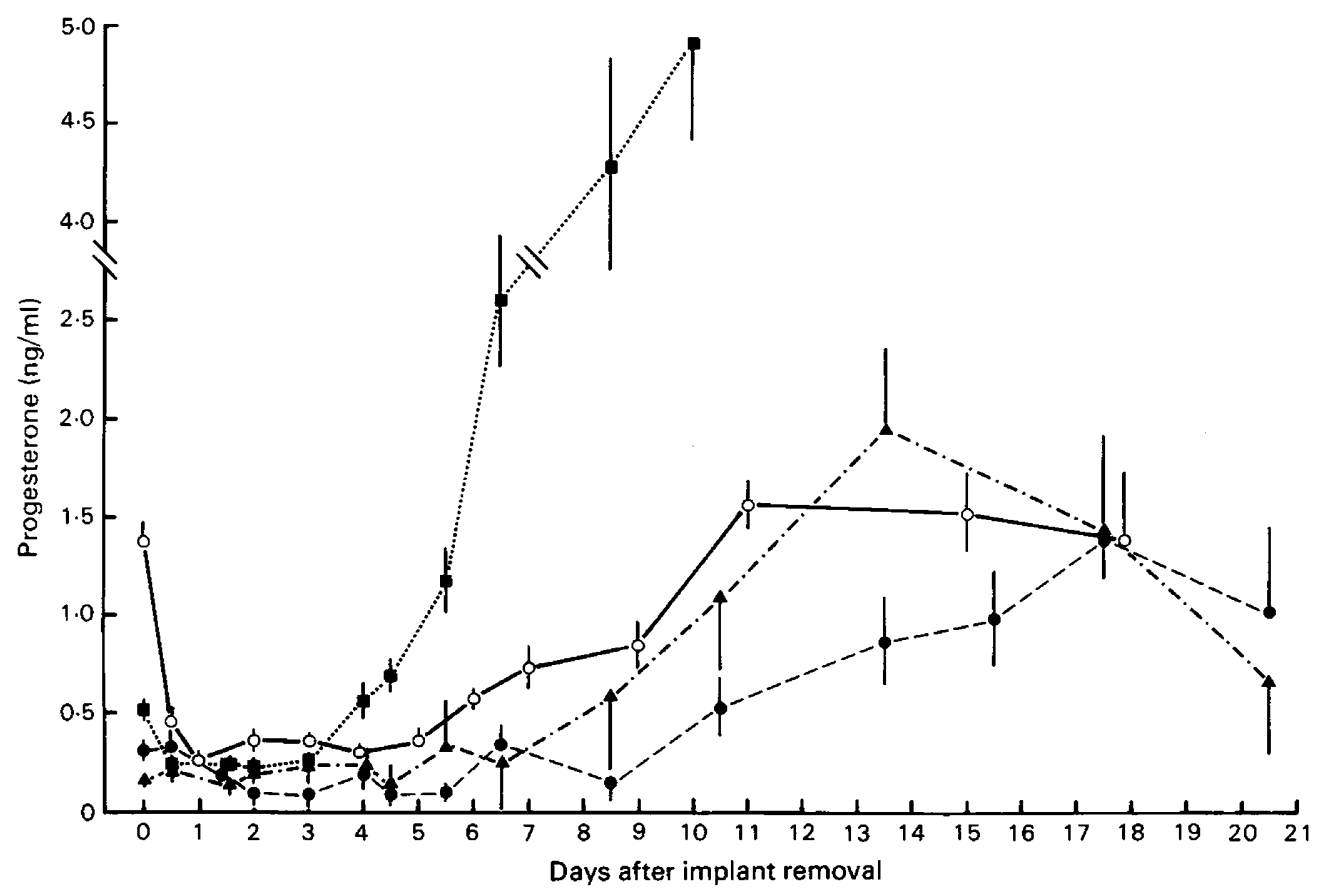

Text-fig. 1. Mean ( \pm s.e.m.) plasma progesterone concentrations for ewes ovulating in Exp. 1

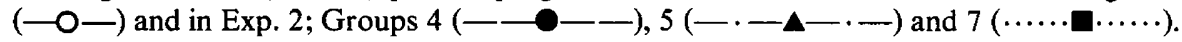

\section{Reproductive behaviour}

No ewes were marked by the rams during the period that the implants were in position. Ten ewes, including 8 of those which showed a gonadotrophin surge, were served by the rams during the 3 days following implant removal and 6 conceived to this service (see Table 3). The remaining 4 ewes returned to oestrus after an interval of 12-23 days, and 2 conceived.

An additional 13 progesterone-treated ewes were marked by the rams during the period 11-29 days after implant removal, and 3 conceived. Five returned to oestrus after a further interval of 15-18 days and 4 conceived. Two control ewes were in oestrus at about 2 weeks after removal of the blank implant, and returned to oestrus at Day 32. A third control ewe showed a fertile oestrus 29 days after implant removal. 


\section{Experiment 2}

\section{Changes in plasma hormone levels following implant removal}

As with Exp. 1, the time of day at which the implant was removed did not appear to influence the pattern of hormonal responses and the data for subgroups A and B have been combined.

Gonadotrophins. Mean ( \pm s.e.m.) plasma gonadotrophin levels at the time of implant removal in 38 ewes treated with a progesterone implant $(2.5 \pm 0.5 \mathrm{ng} \mathrm{LH} / \mathrm{ml} ; 18.2 \pm 1.3 \mathrm{ng}$ $\mathrm{FSH} / \mathrm{ml})$ were similar to those in 16 ewes receiving a blank implant $(2.4 \pm 0.6 \mathrm{ng} \mathrm{LH} / \mathrm{ml} ; 21.9$ $\pm 1.5 \mathrm{ng} \mathrm{FSH} / \mathrm{ml}$ ).

Data on plasma gonadotrophin surges following implant removal are summarized in Table 3. The values of the gonadotrophin surges exhibited by ewes in Groups 5 and 7 during the first $48 \mathrm{~h}$ following implant removal reached $28-175 \mathrm{ng} \mathrm{LH} / \mathrm{ml}$ and $92-305 \mathrm{ng} \mathrm{FSH} / \mathrm{ml}$. The remaining Group-7 ewe showed small elevations of plasma LH $(10 \mathrm{ng} / \mathrm{ml})$ and FSH $(42 \mathrm{ng} / \mathrm{ml})$ at $39 \mathrm{~h}$. The gonadotrophin surge occurred significantly earlier $(P<0.001)$ in the ewes of Group 5 than in those of Group 7, but mean peak heights were similar for the two groups (Table 3). In ewes not treated with PMSG (Groups 4 and 6), plasma gonadotrophins remained at basal levels throughout this period.

One Group-5 ewe showed a second plasma gonadotrophin surge at about $80 \mathrm{~h}$ following implant removal. A late surge in plasma gonadotrophins, occurring at $75-95 \mathrm{~h}$, was also observed in 3 Group-4 ewes and in 2 Group-6 ewes. Peak gonadotrophin levels during these later surges ranged from 20 to $75 \mathrm{ng} \mathrm{LH} / \mathrm{ml}$ and 50 to $123 \mathrm{ng} \mathrm{FSH} / \mathrm{ml}$.

Progesterone. Plasma progesterone levels remained below $1 \mathrm{ng} / \mathrm{ml}$ during the 21 days following implant removal in all of the ewes which had not exhibited a gonadotrophin surge, whereas elevated levels were observed in all of the Group- 7 ewes, 7 of the 10 Group-5 ewes and the 5 ewes in Groups 4 and 6 which had shown a gonadotrophin surge. Mean ( \pm s.e.m.) plasma progesterone level for those ewes in Groups 4, 5 and 7 exhibiting elevated levels are shown in Text-fig. 1. Of the 2 Group- 6 ewes having a gonadotrophin surge, one showed a slow rise in plasma progesterone concentration to $0.7 \mathrm{ng} / \mathrm{ml}$ on Days 9 and 11 , followed by a fall and a subsequent rise to $1.25 \mathrm{ng} / \mathrm{ml}$ on Day 18 . The other showed a more rapid rise to $1.95 \mathrm{ng} / \mathrm{ml}$ at $8 \frac{1}{2}$ days and $2.75 \mathrm{ng} / \mathrm{ml}$ at 11 days - a pattern intermediate between that of Groups 5 and 7 .

The plasma progesterone profile for Group-5 ewes (blank implant + PMSG) was similar to that found in Exp. 1, whereas mean plasma progesterone concentration in Group-7 ewes (progesterone implant + PMSG) rose more rapidly and reached a higher level than that observed in ewes of other groups. The 3 control ewes (Group 4) which exhibited gonadotrophin surges showed a delayed slow rise in plasma progesterone concentration, a pattern quite different from that shown by the treated groups of ewes (see Text-fig. 1).

\section{Reproductive behaviour}

No ewes were served by the rams during the period that the implants were in position, or during the period 5-28 days after implant removal.

Data on oestrous behaviour and conception during the first 4 days following implant removal are given in Table 3 . The 2 Group- 6 ewes which showed a plasma gonadotrophin surge were served at about the time of peak gonadotrophin levels, and one conceived. None of the ewes in Groups 4 and 5 showed oestrous behaviour despite the fact that 13 had exhibited a gonadotrophin surge and 10 showed a subsequent increase in plasma progesterone concentration.

Although the time of day at which the implant was removed did not affect the timing of hormonal responses, it appeared to influence the time of occurrence of oestrous behaviour in Group 7 ewes. The mean ( \pm s.e.m.) interval from gonadotrophin peak to mating was shorter for

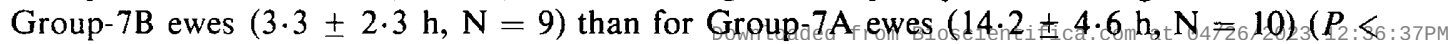


0.05 ), and there was a greater spread in the time of mating of the ewes of Group 7A (from $4 \mathrm{~h}$ before to $36 \mathrm{~h}$ after the gonadotrophin surge) compared to that of the ewes of Group 7B (from 8 $\mathrm{h}$ before to $16 \mathrm{~h}$ after the surge). For both subgroups, the first signs of oestrous behaviour were observed mainly during the 8-h period of the day between 16:00 and 24:00 h: in Group 7A, 7 out of 9 ewes, and in Group 7B, 5 out of 9 ewes were mated during these hours.

\section{Discussion}

In comparing the results of the two experiments reported here, it should be borne in mind that there were differences between the two experiments in the dose of progesterone employed and duration of treatment. In order to eliminate the adverse local reaction observed in a number of ewes treated with $20 \%$ progesterone implants in Exp. 1, the progesterone content of the implants was reduced to $13 \%$ for Exp. 2. The total amount of progesterone absorbed from the implants (as evidenced by loss of weight) was similar for the two experiments. However, in Exp. 1, this amount of progesterone was absorbed over a shorter period of time thus producing higher plasma progesterone levels during the treatment period. Plasma progesterone and basal gonadotrophin levels in ewes treated with blank implants were also higher in Exp. 1 than in Exp. 2. However, within each experiment, plasma LH concentrations at the time of implant removal were similar for ewes treated with a blank or progesterone implant, but plasma FSH level was significantly elevated in ewes treated with oestradiol followed by progesterone (Group 3). We cannot explain the reason for this rise in FSH concentration, but neither oestradiol (Group 1) nor progesterone alone (Groups 2,6 and 7) produced such an elevation.

Some of the control ewes treated with blank implants also exhibited signs of ovarian activity. It seems unlikely that the oestrous behaviour shown by control ewes in Exp. 1 was stimulated by the single injection of oestradiol given at the time of implant insertion, but it is possible that, in both experiments, the responses of the control ewes were triggered by the presence of rams. It is known that the onset of the breeding season can be advanced by the sudden introduction of rams to anoestrous ewes but, in British breeds of sheep, this advancement seldom exceeds 6 weeks (Lindsay, 1976). However, Bellinger \& Mendel (1974) found that the introduction of rams to anoestrous Suffolk and Hampshire ewes during the months of April to June provoked a degree of ovarian activity associated, in some cases, with behavioural oestrus and, occasionally, a fertile mating.

The results for tiie treated groups of ewes extend previous observations on hormonal changes and the induction of oestrus in anoestrous ewes treated with progesterone implants. Progesterone treatment alone appears to be more effective in provoking gonadotrophin surges in anoestrous ewes as the natural breeding season is approached. Thus the percentage of ewes showing such surges was $11 \%$ in early June (Group 6), 28\% in mid-July (Groups 2 and 3) and 90\% in July-August (Saba et al., 1975). This progressive change in the effectiveness of progesterone is consistent with the known seasonal variation in the response of anoestrous ewes to progesterone treatment (Robinson, 1971). It may reflect an increase in the sensitivity of the hypothalamopituitary system to endogenous oestrogen with the approach of the breeding season, since Land, Wheeler \& Carr (1976) have found that ovariectomized ewes show a reduced response to the stimulatory effects of exogenous oestrogen on LH release during anoestrus. Furthermore, in agreement with the work of others (Renfro \& Dutt, 1970; Gordon, 1975), the results of the present experiments suggest that progesterone treatment during July is more effective in initiating cyclic activity than is treatment during June, which would be consistent with a reduction in the refractoriness of the hypothalamo-pituitary system during late anoestrus. However, it cannot be ruled out that the responses of the ewes treated in July might, to some extent, have been a consequence of the higher plasma progesterone levels achieved in Exp. 1. 
An important difference between the present results and those reported earlier (Saba et al., 1975 ) is that ewes which showed gonadotrophin surges following progesterone treatment during June and July also exhibited oestrous behaviour, whereas the majority of ewes treated during the later stages of anoestrus (July-August) had 'silent' ovulations. Robinson (1959) has emphasized the importance of progesterone before oestrogen in inducing cyclic activity in spayed ewes, and the low incidence of oestrous behaviour reported by Saba et al. (1975) may therefore have been a consequence of the relatively low plasma progesterone levels achieved during implantation.

The importance of progesterone priming as a prerequisite for oestrous behaviour is also evident when the responses of ewes treated with PMSG or PMSG plus progesterone are compared. Treatment with PMSG alone was very effective in provoking a gonadotrophin surge at $27 \mathrm{~h}$ after injection, but none of the ewes showed oestrous behaviour although elevated plasma progesterone levels during the period 9-20 days after the PMSG injection suggested that the ewes had ovulated and formed active corpora lutea. In marked contrast, ewes treated with PMSG after a period of elevated plasma progesterone concentration (Group 7), showed a gonadotrophin surge at $33 \mathrm{~h}$ after the PMSG injection which was associated with a fertile oestrus. The $5 \mathrm{~h}$ delay in the occurrence of the gonadotrophin surge in progesterone + PMSG-treated ewes compared with those receiving PMSG alone may reflect the time required for release of the pituitary from progesterone inhibition. An even longer delay was observed in ewes showing a gonadotrophin surge following treatment with progesterone implants in Exp. 1. The higher plasma progesterone levels at the time of implant removal might account for this delay since, in Exp. 1, plasma progesterone concentration had not reached basal levels by $12 \mathrm{~h}$ after implant removal (see Text-fig. 1) and the pituitary would therefore have been under the influence of elevated progesterone levels for a longer period.

Hulet \& Stormshak (1972) found that fertility was higher in anoestrous ewes treated with 2 mg oestradiol-17 $\beta$ at the time of insertion of a progesterone implant, but we found no evidence of such an improved response. On the contrary, the proportion of ewes exhibiting a gonadotrophin surge and oestrous behaviour following removal of the implant was lower for Group 3 than for Group 2, although this difference was not statistically significant because of the small number of ewes in Group 2. The lack of a beneficial effect of oestradiol in Exp. 1 may have been a consequence of the smaller dose of oestradiol administered $(0.5 \mathrm{mg})$, and the effects of higher doses should perhaps be investigated.

A remarkable feature of the ewes treated with progesterone + PMSG in the present experiments was the rapidity with which plasma progesterone levels increased following treatment (see Text-fig. 1), and this may have contributed to the high level of fertility observed for the Group- 7 ewes. The early rise in plasma progesterone concentration may have resulted from the rapid formation of an actively secreting corpus luteum, or perhaps from the formation of several corpora lutea as a consequence of multiple ovulations stimulated by the PMSG injection. Boland \& Gordon (1973) found that the administration of 500 i.u. PMSG to anoestrous ewes following progestagen treatment increased the number of multiple ovulations, and the higher lambing rate shown by Group 7 (1.9 lambs/ewe lambing) compared with Groups 2 and 3 (1.2 lambs/ewe lambing) would be consistent with such an explanation. Nevertheless, treatment with PMSG alone (Group 5) did not result in an early rise in plasma progesterone level.

It has been suggested that the interval between the gonadotrophin surge and the occurrence of oestrous behaviour may have some bearing on fertility at an induced oestrus (Echternkamp \& Lunstra, 1978), and in an earlier paper (Cunningham, Saba \& Millar, 1977) we reported that the time of day at which a progesterone implant was removed from ewes treated in late anoestrus affected the interval from removal to the gonadotrophin surge. No such effect was observed when ewes were treated with progesterone + PMSG in mid-anoestrus, as in the present experiments, although time of day of removal of the implant did have an effect on the interval from the gonadotrophin surge to the occurrence of oestrous behaviour. Thus although there was 
a $12 \mathrm{~h}$ difference between Groups 7A and 7B in the times of removal of the implants $(17: 30 \mathrm{~h}$ and $05: 30 \mathrm{~h}$ ), and of the occurrence of the gonadotrophin surge, mean times of mating for Groups 7A and 7B differed by only $2 \mathrm{~h}$. These observations suggest that there may be diurnal variations in the effectiveness of the centres responsible for oestrous behaviour. However, time of day of removal of the implant had no significant influence on fertility at the induced oestrus.

We thank the National Institute of Arthritis, Metabolism and Digestive Diseases, U.S.A., for the gift of pituitary hormone preparations used in the radioimmunoassays; Miss $\mathrm{C}$. N. Hebert for the statistical analyses; and Mr P. Harrington, Mr R. Jackson, Mrs A. M. Kerry, Mrs V. Mackintosh, Mr T. C. Martin and Mr P. M. Raby for valuable technical assistance.

\section{References}

Abraham, G.E., Swerdloff, R., Tulchinsky, D. \& Odell, W.D. (1971) Radioimmunoassay of plasma progesterone. J. clin. Endocr. Metab. 32, 619-624.

Bellinger, L.L. \& Mendel, V.E. (1974) A note on the reproductive activity of Hampshire and Suffolk ewes outside the breeding season. Anim. Prod. 19, 123126.

Boland, M.P. \& Gordon, I. (1973) Oestrus and ovulatory response to progestagen-PMS treatments in anoestrous ewes. J. Dept. Agric. Fish., Ireland 70, $65-70$.

Challis, J.R.G., Heap, R.B. \& Illingworth, D.V. (1971) Concentrations of oestrogen and progesterone in the plasma of non-pregnant, pregnant and lactating guinea-pigs. $J$. Endocr. 51, 333-345.

Cunningham, N.F. \& Hebert, C.N. (1973) A solidphase radioimmunoassay for ovine follicle-stimulating hormone. J. Endocr. 58, 239-249.

Cunningham, N.F., Saba, N. \& Millar, P.G. (1975) Release of progesterone from silicone rubber implants in vitro, and the effects of the implants on plasma progesterone levels in sheep. J. Reprod. Fert. 43, 555-558.

Cunningham, N.F., Saba, N. \& Millar, P.G. (1977) The effects of progesterone and oestradiol-17 $\beta$ treatment on plasma hormone levels and on the reproductive behaviour of ewes in late anoestrus and early in the breeding season. Res. vet. Sci. 22, 324-329.

Echternkamp, S.E. \& Lunstra, D.D. (1978) Causes for decreased fertility in out-of-season mated ewes. Theriogenology 10,65-71.

Gordon, I. (1971) SC-9880-progesterone applications in the induction of early breeding in sheep. J. agric. Sci., Camb. 76, 343-346.

Gordon, I. (1975) Hormonal control of reproduction in sheep. Proc. Br. Soc. anim. Prod. 4, 79-93.

Hulet, C.V. \& Stormshak, F. (1972) Some factors affecting response of anestrous ewes to hormone treatment. J. Anim. Sci. 34, 1011-1019.

Land, R.B., Wheeler, A.G. \& Carr, W.R. (1976) Seasonal variation in the oestrogen induced $\mathbf{L H}$ discharge of ovariectomized Finnish Landrace and Scottish Blackface ewes. Annls Biol. anim. Biochem. Biophys. 16, 521-528.

Lindsay, D.R. (1976) Mating behaviour in sheep. In Sheep Breeding, pp. 338-344. Eds D. E. Robertson \& R. J. Lightfoot. W. Aust. Inst. Technology, Perth.

Mauer, R.E., Revenal, P., Johnson, E.S., Moyer, R.H., Hirata, A. \& White, W.F. (1972) Levels of luteinizing hormone in sera of ewes near the time of estrus as determined by radioimmunoassay. J. Anim. Sci. 34, 88-92.

Renfro, R.E. \& Dutt, R.H. (1970) Reproductive response of one-year-old anestrous ewes to hormone treatment. J. Anim. Sci. 30, 326, Abstr.

Robinson, T.J. (1959) The estrous cycle of the ewe and doe. In Reproduction in Domestic Animals, Vol. 1, pp. 291-333. Eds H. H. Cole \& P. T. Cupps. Academic Press, New York.

Robinson, T.J. (1971) The seasonal nature of reproductive phenomena in the sheep. II. Variation in fertility following synchronization of oestrus. J. Reprod. Fert. 24, 19-27.

Saba, N. (1976) Adsorption of free steroids with charcoal-gelatin disks in radioimmunoassays. $J$. Endocr. 70, 141-146.

Saba, N., Cunningham, N.F., Symons, A.M. \& Millar, P.G. (1975) The effect of progesterone implants on ovulation and plasma levels of LH, FSH and progesterone in anoestrous ewes. J. Reprod. Fert. 44, $59-68$.

Symons, A.M. (1973) Levels of oestrogen and progesterone in the cow during the last month of pregnancy. J. Endocr. 56, 327.

Symons, A.M., Cunningham, N.F. \& Saba, N. (1974) The gonadotrophic hormone response of anoestrous and cyclic ewes to synthetic luteinizing hormonereleasing hormone. J. Reprod. Fert. 39, 11-21.

Symons, A.M., Cunningham, N.F., Saba, N. \& Millar, P.G. (1974) Circulating progesterone levels in anoestrous sheep with silicone rubber progesterone implants. J. Reprod. Fert. 41, 475-477. 